Article

\title{
O cei na Vulavula? Insights and Regrets of a Foreign Geoscientist in the Pacific Islands
}

\author{
Patrick D. Nunn (D)
}

Citation: Nunn, P.D. O cei na

Vulavula? Insights and Regrets of a Foreign Geoscientist in the Pacific Islands. Geosciences 2021, 11, 182. https://doi.org/10.3390/ geosciences 11050182

Academic Editors: Michael G. Petterson and Jesus Martinez-Frias

Received: 13 April 2021

Accepted: 20 April 2021

Published: 22 April 2021

Publisher's Note: MDPI stays neutral with regard to jurisdictional claims in published maps and institutional affiliations.

Copyright: (C) 2021 by the author. Licensee MDPI, Basel, Switzerland. This article is an open access article distributed under the terms and conditions of the Creative Commons Attribution (CC BY) license (https:// creativecommons.org/licenses/by/ $4.0 /)$.
School of Law and Society, Australian Centre for Pacific Islands Research, University of the Sunshine Coast, Maroochydore, QLD 4558, Australia; pnunn@usc.edu.au

\begin{abstract}
From over three decades of close contact with Pacific Islands geoscience, the author reflects on key issues (what he wished he had known earlier) about the nature of islands, their landscapes and their peoples. Experience elsewhere in the world rarely prepares you for the Pacific, from its youthful and often tectonically unstable landscapes to the understandings of its inhabitants, which are sometimes time-consuming and difficult to access yet frequently illuminating. Mysteries abound in Pacific geoscience, often in places as difficult to access as they ever were, yet which have the potential to inform global ideas about earth-surface evolution. Geoscience research and enterprise remain largely foreigner-driven in the Pacific Islands, which is often anathemic to sustainability, privileging ideas that are uncritically assumed to be shared by their peoples. An opportunity exists for Pacific peoples to own the geoscientific knowledge and potential of their islands.
\end{abstract}

Keywords: Pacific; knowledge; island geology; traditions; last interglacial; sea-level change; island flank collapse; lithospheric flexure; radiocarbon dating

\section{Background}

A few days after I arrived in Fiji, so did Eric and Nigel, the first tropical cyclones to hit Suva directly in more than forty years. Terrified, alone, I had ample time to reflect on how the Pacific was different to anywhere I had been before. Which was not a bad lesson for a geoscientist schooled — as most are still—in ancient continental landscapes, fetching up in a place where the oldest rocks might at a push be Eocene in age but where really almost everything you could see formed within the last few million years.

Given that the oldest rocks on earth had just been dated to around four thousand million years, it would have been easy to feel a bit short-changed. Yet that never happened to me for, despite the youth of the Pacific Islands, I discovered they were far more boisterous than any landscapes I had ever before encountered. Things moved up and down, they sank, collapsed, slipped, were periodically hammered by huge waves, pummeled by hurricanes, split and rocked in massive earthquakes, and even blasted in volcanic paroxysms around the entire planet.

Of course, this was not an instant realization. Like no doubt most other overseastrained geoscientists arriving in the Pacific, I spent ages trying to mold the Pacific Islands to my worldview, but in the end it proved pointless. To celebrate this understanding, I wrote a book, Oceanic Islands, that explained the origins of islands like those in the Pacific, paying special attention the ways they were different from continental landmasses [1]. "Every island we see today in the world's ocean basins began life as an ocean floor volcano", I wrote, something which I found really helped engage the Pacific Island students I taught at the University of the South Pacific. There is an entire chapter on "tectonics" in this book, emphasizing the importance of land-level movements to island evolution, and another on island "landscapes" that attempted to make geomorphology relevant to students from Pacific islands.

After about ten years of living in the Pacific Islands, I felt a growing intimacy with the region's geology, felt I was really getting to grips with its contrasts and its enigmas. I 
almost dared to think I belonged. One thing that brought me crashing back to earth was the day I left to visit the Fiji island of Beqa for the first time, a Pliocene volcano clearly shaken by proximal plate convergence during the late Quaternary [2]. Getting into the boat at Navua that Tevita Moce, my Fijian research assistant, and I had hired, the boatman called out loudly $O$ cei na vulavula (Who's the foreigner)? I knew enough Fijian to understand this, something the boatman had clearly adjudged improbable, but as we rocked and thumped our brisk way over the water to Beqa I reflected on the fact that I would always be a foreigner in this part of the world, for, however much you reinvent yourself, part of you will always appear as you were at the beginning. A bit like Beqa really, finding itself unexpectedly shaken up after a couple of million years of senescence.

This paper is more self-indulgent than anything I have written before, but I hope there is some value in it. I have achieved several insights into the geology of the Pacific Islands of which I am proud, but I also regret not having done more to drive the agenda of empowering Pacific Island peoples to lead geoscience research within their region.

\section{Insights from Ancient Stories}

Like many other specialists trained in the global West, geoscientists trained in European universities are taught unquestioningly about the need to compartmentalize knowledge. The reason, to paraphrase geographer Halford Mackinder, is that "knowledge is one. Its division into subjects is a concession to human weakness", meaning that the human brain cannot grapple with all knowledge; the age of the polymath is long gone. You might think that this to be a universal truth, but it is not.

Pacific peoples generally think of everything as far more connected. The Earth is linked to the sky and anchored in the depths of the ocean. Just as one's daily actions need justifying to one's departed ancestors, so they need to acknowledge the security of your children. The path of the spirits is just beyond that grove of coconuts, it follows the road into town for a few miles. God binds everything together, the past and present, the sand on the beach, the rocks making the mountains. You need to look through only one lens to make sense of everything in this world.

Most geoscientists educated in Western systems find it hard to "believe" in God. They invariably consider it risible that anyone might consider God to have created and control everything. That is their worldview and of course they are entitled to it. Yet when you enter a context in which the inhabitants have a contrasting worldview to your own, what right do you have to try and impose yours and the value system it informs?

This was once a thorny issue for me. I had been taught the truths-that plate tectonics could explain the formation of every part of the Pacific Basin, that the sea level rose and fell in sequence with the formation and dissolution of land-ice sheets, that radiometric dating could place absolute ages on rocks and their organic associates-and any suggestions to the contrary were clearly ridiculous. Suggestions like islands being alive, wandering around the ocean, fighting one another; or islands being fished up from the ocean floor by the giant demigod Maui so that his kinfolk might have places to live; suggestions like islands being thrown down from the sky by angry gods or through swarms of flying imps firing scattershot across the ocean; like giant spears being launched, making holes in the rocks, or giant feet pushing one island away from its neighbors; islands being supported by undersea pedestals of rock, often precariously, guarded by sharks or giant sailfish; or even the presence of underground or undersea streams connecting distant islands.

After a while, at least in my case, Western arrogance diminished and was replaced by a respect for such deeply held views and a quest for meaning in such stories. I cannot think of an instance in which this change of attitude has not improved my understanding of the islands' geological history.

Take the islands off the north coast of Efate Island in Vanuatu, the ones near Piliura Village. The local people tell a story about how there used to be only two islands thereMalow and Tama Mora. They were friends and accustomed to chat to each other, until one day two new islands-Pele and Kakula—appeared and blocked the friends' view of each 
other. Enraged, Malow and Tama Mora attacked the two new arrivals, but they proved too strong, and Malow and Tama Mora sank. Today, when it is quiet and the sea is calm, you can sail across the site of sunken Tama Mora and you can hear people talking and roosters crowing on the island below. These stories are unpublished, told to Christy Haruel by the people of Piliura and Loanamoa (Efate Island, Vanuatu) in January 2007.

There are three broad ways to interpret such stories. You can dismiss them as fantasy, as cultural fictions. At the other end of the spectrum, you can regard them as literal. In the middle, you can view these kinds of stories as allegory, as culturally rooted and culturally filtered memories of actual events-in this case, most plausibly, as the appearance of two young volcanic islands and the submergence of two older ones, a composite memory of volcanism and tectonism. In my experience, most geoscientists take a while to shift from the fantasy end of the spectrum towards its center, a process that has become easier over the last few decades since the pioneering work of Dorothy Vitaliano [3] and an influential Geological Society of London collection [4]. Yet even for geoscientists willing to accept the middle position, questions remain — questions like how much can be read into details of volcanism, how far is the sequence of events (emergence-submergence) plausible, and what can be inferred from the memories of contemporary experiences at sunken Tama Mora.

Studies of similar Pacific stories [5-8] suggest that details of particular phenomena and sequencing are generally valid, although it is important to collect several versions of such stories (not just one) so as to assure a median narrative rather than possibly a fringe one. What is especially interesting about the Tama Mora story is the contemporization of memory through the belief that people and roosters can be heard below the ocean surface, a way of keeping alive (traditionally in the absence of literacy) the memories of catastrophic events for the purpose of informing subsequent generations. In Fiji and Yap (Federated States of Micronesia), memories of land submergence are kept alive by cultural protocols that must be followed whenever local residents sail across sites of submerged lands their ancestors inhabited; such traditions are little different to placing flowers or saying prayers at the grave of a loved one $[9,10]$.

In the Pacific and elsewhere, stories involving past catastrophe are invariably linked to people's actions [11,12]. Just as "bad behavior" is considered to lead to punishment, from a volcanic eruption to extreme climate events [13,14], so "appropriate behavior" incorporating the divined will of gods (today mostly "global" ones) is considered to prevent such punishment. It is deceptively easy to ridicule such beliefs, but research has shown how influential they are on human behavior in key instances [15,16], and my experience is that this influence is far more widespread than might even be inferred from these studies. Additionally, rather than seeking to replace such beliefs, a more helpful and nuanced approach is to acknowledge them and use them to facilitate effective and sustainable adaptation, something pioneered by Shane Cronin for volcanic hazards in the Pacific Islands [17-19].

Over the last two decades in particular, the interconnectedness of Pacific Island people's knowledge has been repeatedly demonstrated to me. I select one example for illustration: that of the Maui myths involving the "fishing-up" of Pacific islands [20]. The demigod Maui features in most Pacific Island traditions, and one of his most commonly discussed attributes is an ability to fish up islands from the ocean floor, creating habitable land where none existed before. I argue that numerous details in many such stories show that they were created originally from observations of shallow-water volcanism, which agitated the ocean surface (as would a wriggling fish) and created an island-as happens regularly in the volcanic islands of Tonga and elsewhere in the region ([21], pp. 140145). Thus, the distribution of Maui myths within the Pacific (Figure 1) likely includes both places where shallow-water volcanism occurred within the 3500 years of its human occupation and those to which stories were carried. The potential of using such information to reconstruct patterns of historical volcanism remains largely untapped. 


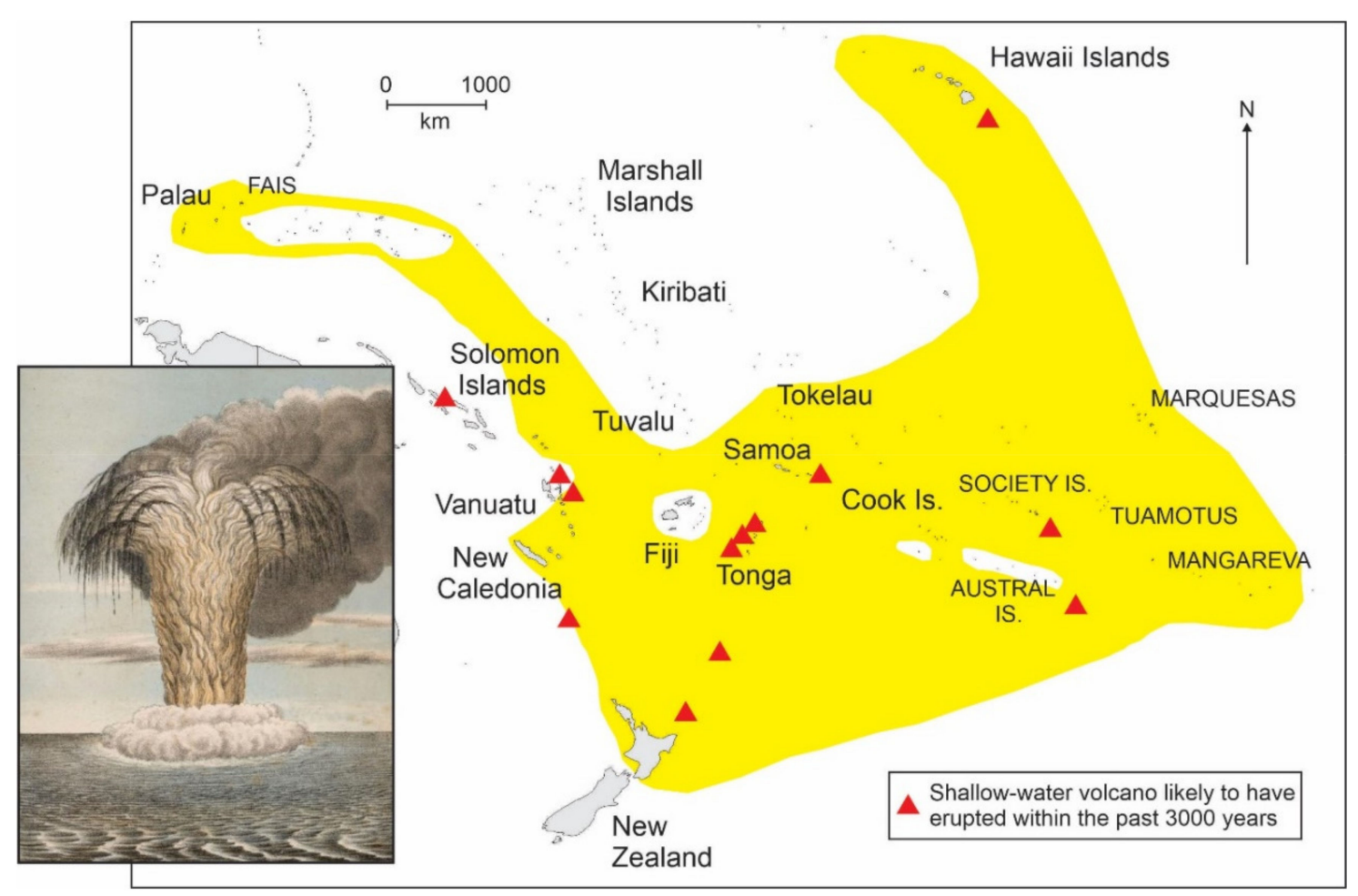

Figure 1. Map of the Pacific region showing the known distributions of Maui "fishing-up" stories and shallow-water volcanism within the past 3500 years (after 20). Inset is a hand-colored lithograph (1886) of a shallow-water volcanic eruption in Tonga; note the resemblance of the eruption plume to a giant fish.

\section{The Significance of Obscured Knowledge}

Many higher Pacific Islands are uncommonly wet places because of the orographic rainfall they receive; parts of Pohnpei where I have been working have recently receive over eight meters of rainfall annually. All this wetness weathers bedrocks, creating thick regoliths that frustrate engineering works, and produces dense vegetation cover, often the ubiquitous "rainforest". The combination of dampness, regolith and plants means that it is sometimes very difficult to find exposures of the bedrock poking through the ground surface; sometimes you just have to follow river valleys or coasts. So it is no wonder new insights are periodically attained.

Look to the southwest on a clear day in Suva, the capital of Fiji, and sometimes you can see the faint silhouette of Nabukelevu, the massive youthful volcano at the western extremity of Kadavu Island. The first time I visited the islands of Kadavu it was to learn more about the timing of the most recent volcanic eruption at Nabukelevu, but it was a frustrating experience for the mountain was then cloaked in rainforest, the only "paths" being those made by wild pigs, which proved true territorial aggressors. During the day I sought exposures of datable material in vain, but after dark, enjoying kava in Daveqele Village made with local spring water, I gleaned far more. Local residents told stories about the last great eruption of Nabukelevu, stories involving the "god" $(v u)$ of Ono Island battling that of Nabukelevu in the sky, the outfall producing ash falls and even creating entire islands. Although I thought this merely a good story at the time, it acquired new meaning after the discovery [22] that the most recent eruption at Nabukelevu took place within the period of these islands' human occupation, about 3000 years ago, rather than the 50,000 years that I first estimated [23]. Therefore, the "legend" was correct, my instinct wrong, a rebuff to geoscientific empiricism that left me duly chastened.

For many years, I collaborated in the Pacific with Bill Dickinson, once a colonialera geologist in Fiji, later President of the Geological Society of America. Bill visited almost every Pacific Island group, writing at length about ceramic petrography [24] and 
island tectonics $[25,26]$. During his time in Micronesia, Bill became very exercised by whether or not thermal rejuvenation of the oceanic lithosphere may have led to faster late-Quaternary subsidence rates than would be expected for oceanic central volcanoes in particular places [27]. I got to help him answer that question, for although Bill had scoured the coasts of Pohnpei and nearby islands for outcrops of emergent coral reef, elevations of which would allow late Quaternary subsidence rates to be calculated, he found none-but I did! On Penieu Island off the main island, I found three outcrops of Last Interglacial reef (Figure 2), the elevations of which suggested subsidence rates as high as $0.91 \mathrm{~mm} /$ year, far faster than this volcano's long-term subsidence rate of $<0.03 \mathrm{~mm} /$ year. This result agreed with Bill's notion of thermal rejuvenation here, and also has implications for future sea-level rise impacts.

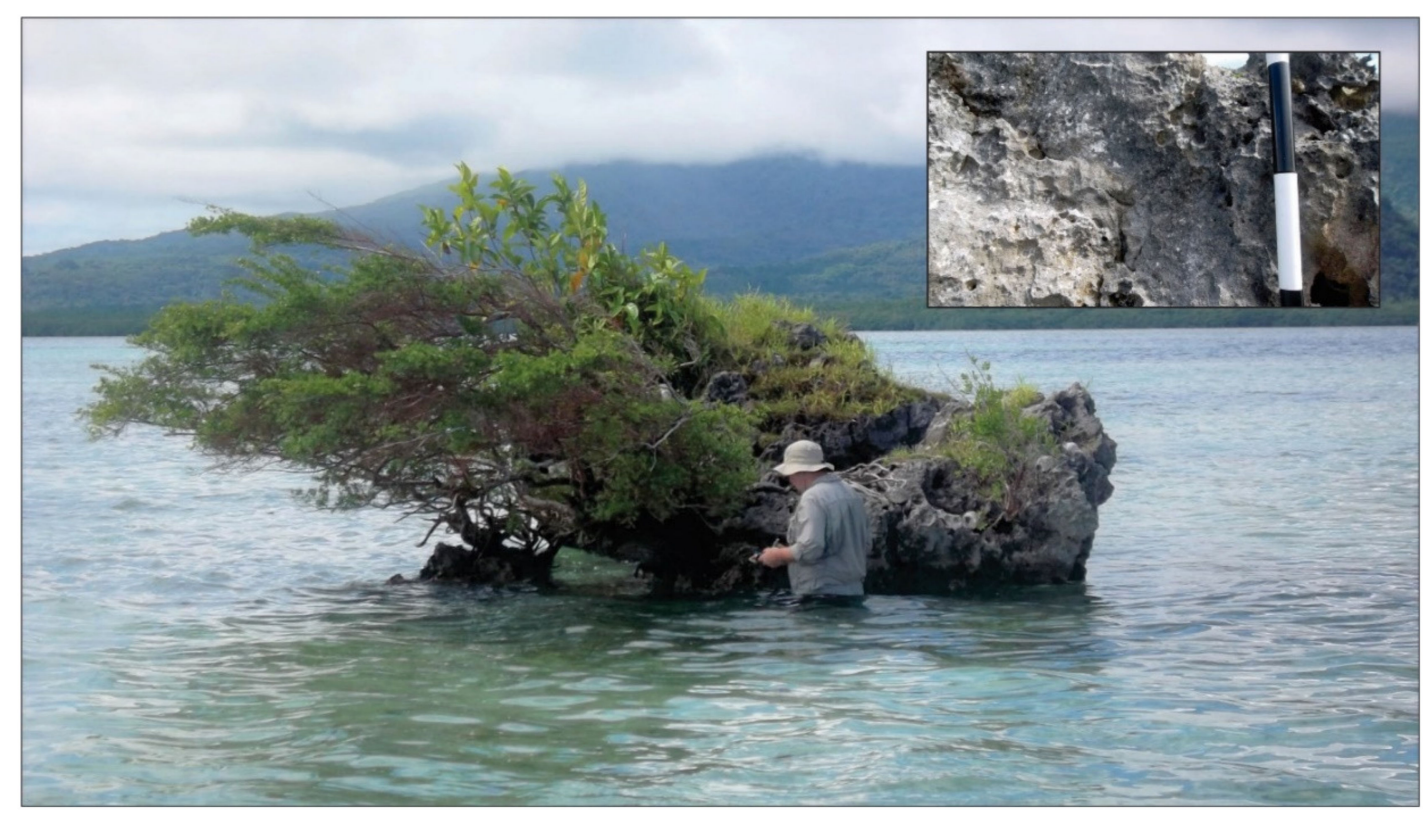

Figure 2. Emerged Last-Interglacial coral reef adjoining Penieu Island, off the south coast of high volcanic Pohnpei Island (background). Inset shows fossil coral in its growth position, demonstrating that this exposure is in situ (Photos: Patrick Nunn).

Studying the history of Pacific peoples and that of their interactions with environmental change, both abrupt/catastrophic and slower/insidious, led me to the somewhat radical belief (for its time anyway) that-like most other groups of people in the world—Pacific societies had been periodically dislodged from their (pre-globalization) developmental trajectories by changes over which they had no control $[28,29]$. A good example is the connection I proposed between sea-level fall AD 1250-1350, the development of a prolonged food crisis for coastal peoples across the Pacific region, and the onset of sustained conflict that brought about fundamental changes in settlement pattern. The key to demonstrating the plausibility of this model is to show that the sea-level fall preceded, perhaps by a few decades, the establishment across high Pacific Islands of fortified mountaintops-hillforts. My recent collaborative work on three areas of Fiji supports this connection [30-32], which I regard as a fine example of environmental determinism - the way in which natural environmental change can determine the course of societal development.

Most hillforts were abandoned on high Pacific Islands within a few decades of European contact and, more importantly, missionization, the success of which was greatly facilitated by the decimation of island populations from introduced disease against which they had never evolved immunity. Hillforts were linked in the minds of new converts with paganism, with times of shame, and their human history largely forgotten. Yet, recent work interpreting the nature and meaning of Pacific island fortifications has in several 
instances been significantly illuminated by stories told by local residents [31]. Like many oral traditions in the Pacific region, the current endangerment of oral knowledge will inevitably—as elsewhere—diminish our understanding of human pasts [33,34]

\section{Lost Knowledge? Favorite Colors, Far-Traveled Heirlooms, Vanished Islands and Earthquake Precursors in Ancient Pacific History}

Tourists visiting New Zealand who become curious about Maori history and culture will not fail to be struck by the central importance of greenstone (pounamu), used not just for fine carvings but also formerly for tools and hunting paraphernalia [35]. Most such greenstones are nephrite jades, products of ophiolites that emerged following tens of millions of years of sustained plate convergence in the western parts of South Island. For this reason, they are not found elsewhere in the Pacific Basin; the New Caledonian ophiolites (found on Grand Terre) do not include jades.

The New Zealand nephrite jades are dense and difficult to carve, but the durability and striking appearance of the final products explain their value and perhaps also their spiritual significance in Maori cultures. I had not really thought much about this until a few years into the excavation of Bourewa, probably Fiji's earliest human settlement, that I directed (with Sepeti Matararaba and Roselyn Kumar) over seven phases between 2003 and 2009 [36,37]. We gradually realized that the overwhelming majority of the lithics (stone tools) we recovered from the site were green, like nothing outcropping locally, and had been fashioned from Tuva River boulders washed downstream from dacite plutonic outcrops at least $7 \mathrm{~km}$ inland (Figure 3). Was the dacite favored because it was green? Someone should try and find out because it might uncover an as-yet unknown connection between the earliest Pacific Islanders and their cultural biases (like "favored colors") that controlled their behavior beyond mere pragmatism. My long-time collaborator, Paula Qereti (Paul Geraghty), has written extensively about Pacific traditions of the fabulous land of Burotukula/Pulotu, and how the etymology of these shows clearly that Pacific Islanders a millennium ago esteemed the color red in the same way as many people today value gold [38].

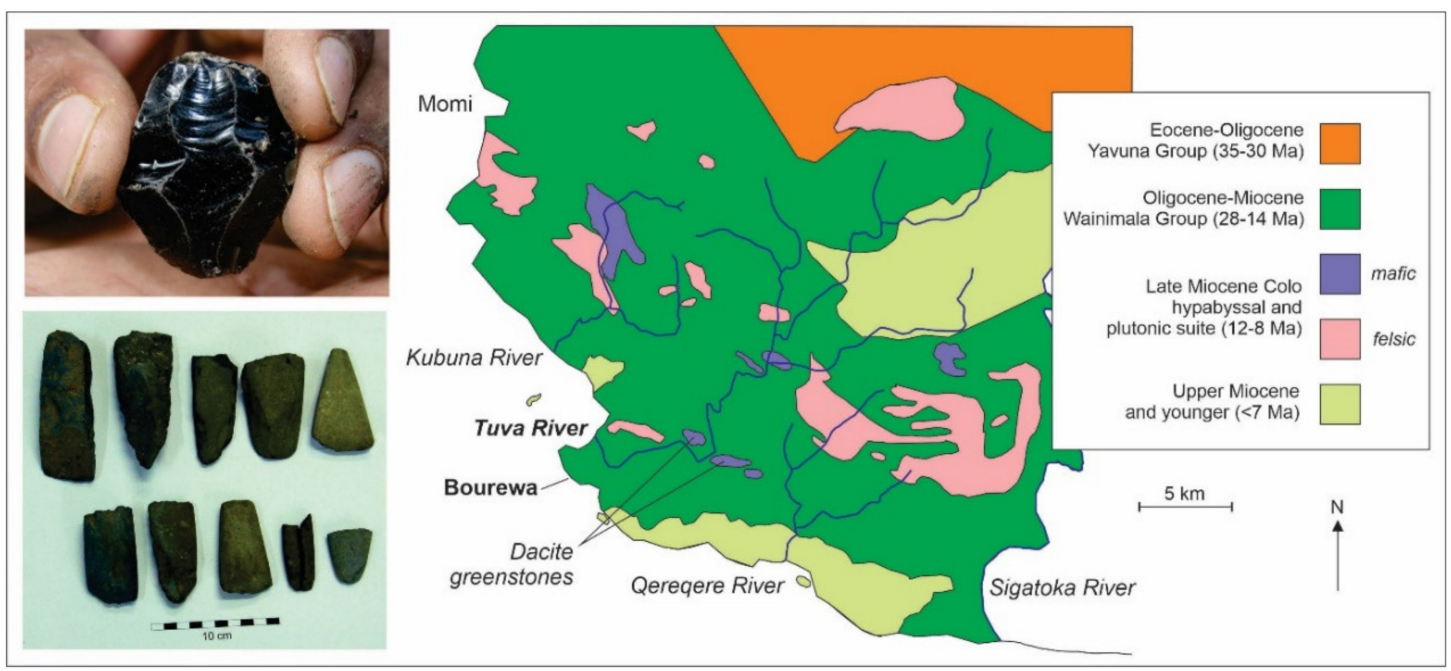

Figure 3. Tertiary geology of southwest Viti Levu Island, Fiji (after [39]), showing the locations of the dacite "greenstone" outcrops in the lower Tuva Valley from which lithics at the Bourewa site, perhaps Fiji's earliest settlement, were probably sourced. Inset bottom left shows a selection of lithics from Bourewa, inset top left shows the piece of obsidian found at Bourewa, imported around 3000 years ago from Talasea in New Britain, Papua New Guinea (Photos: Patrick Nunn).

Another unexpected discovery at the Bourewa site was a piece of obsidian, a volcanic glass that does not occur naturally in Fiji and which was used by the first Pacific Islanders to produce tools with razor-sharp edges. Unlike the obsidian flakes found in archaeological 
contexts throughout this part of the Pacific, the Bourewa obsidian was a core stone (top left in Figure 3), probably one that had been intentionally carved and carried with a group of early settlers as an heirloom [40]. Analysis by Wal Ambrose showed this obsidian to have originated in the Kutau/Bao area of New Britain Island (Papua New Guinea), representing an import across at least $3400 \mathrm{~km}$ of mostly ocean about 3000 years ago.

Sometimes knowledge remains obscure because the idea it might actually exist is just so astonishing. When I first began trying to make sense of the many Pacific islander stories about "vanished islands" I heard, I received considerable push-back from some of my geoscientist peers. For not only did these stories require believing that islands could actually "vanish", which was clearly a nonsense (I was told), but it seemed the only evidence this happened were people's stories, and who could trust those (they said)?

Well luckily around this time, I was avidly reading Stephen Jay Gould and starting to appreciate that non-Western worldviews sometimes had as much explanatory potential as western ones, which emboldened me to stick with my efforts that culminated in my 2009 book Vanished Islands and Hidden Continents of the Pacific [21]. I came across many "vanished island" stories in Fiji, Solomon Islands and Vanuatu that I researched and wrote up with my students. The example here represented a collaboration with Tony Heorake and others, and involved stories from the central Solomon Islands about the disappearance of the island named Teonimanu (Teonimenu). We collected stories from communities throughout the region, most of which recalled how mad jealous Roraimenu from Ali'ite Island caused Teonimanu, to which his wife had eloped, to be destroyed [41]. While the stories describe the succession of waves that apparently razed the island, it is probable that Teonimanu subsided abruptly as a result of a seafloor landslide triggered by an earthquake that also caused tsunamis to wash across the island, giving onlookers the sense that it was being "destroyed by waves" (Figure 4); similar stories are known from Vanuatu [10].
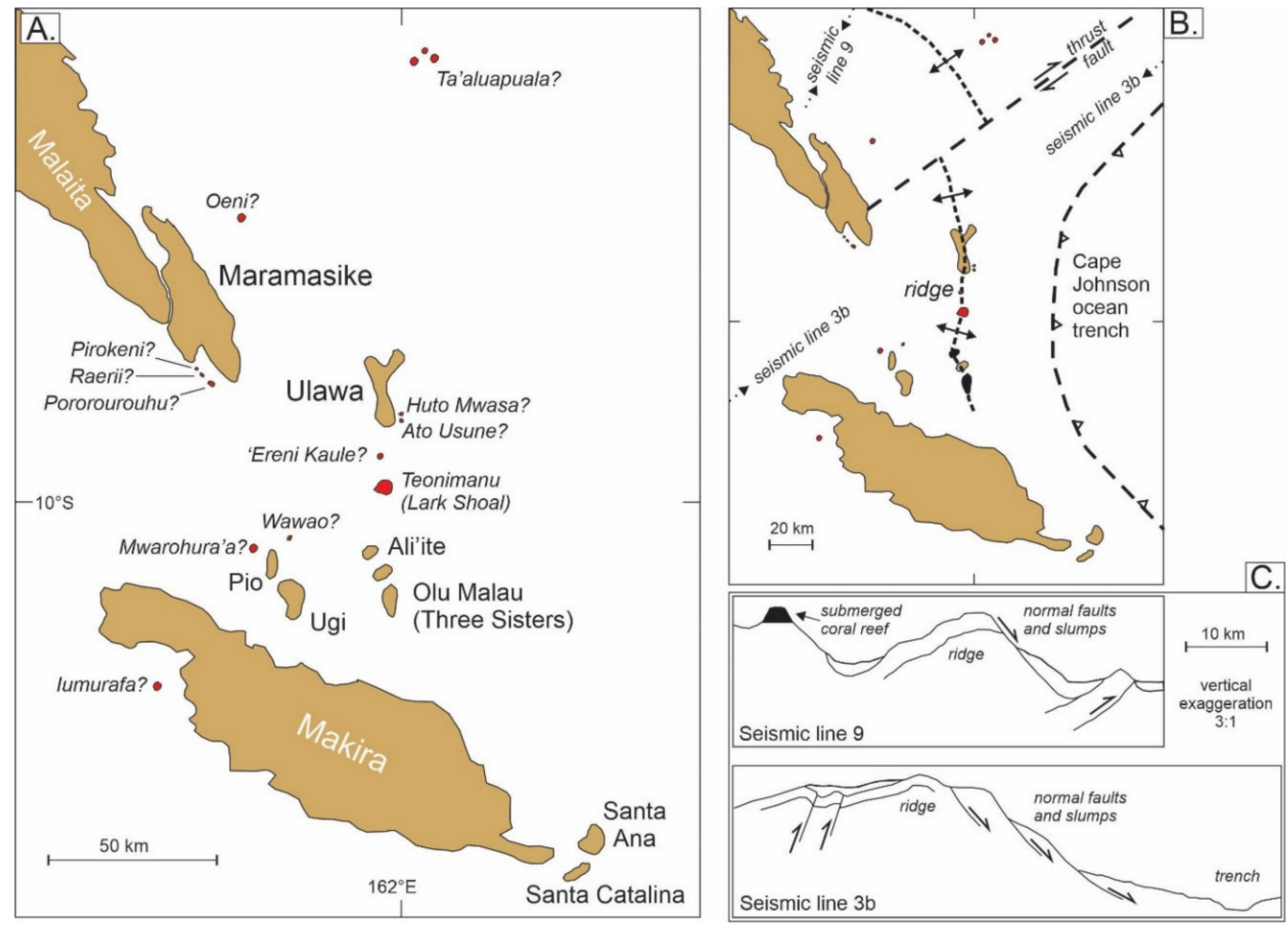

Figure 4. The central Solomon Islands (after 40). (A)—modern islands and "vanished" islands (shaded red) recalled in oral traditions. (B)—structure of the same area, showing the Ulawa-Teonimanu-Olu Malau (UTOM) Ridge, the eastern flank of which dips steeply to the Cape Johnson Trench. (C) — simplified interpretation of two seismic lines [42] located in B showing a submerged reef-capped island and evidence of a long history of slumping along the eastern flank of the UTOM Ridge. 
I am also intrigued by hints of knowledge in Pacific cultures concerning traditional/nonseismic earthquake precursors, a topic of growing interest elsewhere in the world over the past decade $[43,44]$. Not least because seismicity is such a feature of many Pacific Island environments, I suspect there was once a broad range of culturally grounded earthquake precursors in Pacific Island societies, but most details have been almost entirely lost today. Evidence for this view comes from a story of the demigod Maui, who in the islands of Tonga resided under the earth, bearing it on his shoulders.

"His nodding, when disposed to sleep, produces the earthquake; when this occurs, the people stamp the ground, and vociferate, to awake the god, lest he should nod so violently as to upset the island into the sea", ([45] p. 113).

Similar practices were once followed elsewhere in the world and may hint at some now-lost earthquake precursors that elicited such behavioral responses. Within the last decade, in conversations in various parts of Fiji, I have learned of comparable traditions. Framed within the belief of rural dwellers that unusual weather conditions, especially prolonged dryness and excessive heat (when "the earth is begging for water"), will often lead to catastrophe ("something is going to happen"), this may involve flooding, extreme waves or even earthquakes. My questioning of Shiu Raji shows that she and her contemporaries were convinced the intense heat and "stillness of the air" for several weeks in the early 1980s were a precursor to an earthquake that affected the Sawani area of southwest Viti Levu Island; she explained that the land was fevered and that this could be broken only by a release of pressure, such as an earthquake (bhookamp) would provide. Recent research demonstrates just such a connection, showing that the onset of the Indian monsoon can trigger micro-earthquake swarms [46].

What I suggest Pacific stories about vanished islands and earthquake precursors illustrate is that people in the past had ways of rationalizing natural events/disasters that evolved to be robust and practical within the contexts they occupied. The initial reaction of (Western-schooled) outsiders/professionals is naturally to dismiss these stories because they are expressed in such "non-scientific" terms and involve suggestions/associations that appear ludicrous to people trained to compartmentalize knowledge. But evidently they are not, something that might reasonably force geoscientists to re-examine the validity of some of the assumptions that underpin the practice of their research.

\section{Knowledge for Whom? Developing and Applying the "Roko Vola Test"}

Shortly after I moved to the Pacific Islands, I traveled to the island of Moala in southeast Fiji interested in just one thing-discerning from morphology and lithology how the level of the island had changed. My model was simple and borne out by my field observations [47]. Like the other islands (Matuku and Totoya) in the eponymous group, Moala had ascended a lithospheric (crustal) flexure associated with now-halted convergence of the Indo-Australian Plate beneath the Fiji microplate, a process that had led to the development of extensional faulting and uplift and now, after Moala had passed over the flexural crest, subsidence, which was amplifying the rate of sea-level rise there (Figure 5).

To me, comparatively fresh from a PhD in Quaternary geology, newly acquainted with tectonic landscapes, asking such questions seemed obviously justified. Yet now I reflect on just how useless such information really is, at least to the people it affects the most. I met no-one on Moala who was curious about my research questions and at first, to be honest, I could not understand why. Then it occurred to me that the anomalous Quaternary tectonic history of their island was a very long way down the list of issues that they considered important. So I asked myself whether I should start to care more about the landsliding and loss of fertile land, about the growing encroachment of the sea on the land, about the earthquakes, about reef degradation, about potable water supply, about others histories and the culturally fashioned imperatives emanating from these. Visiting Moala was something of an epiphany for me and I am forever grateful to the late Roko Isireli Vola Draunidalo for helping me reach it. 


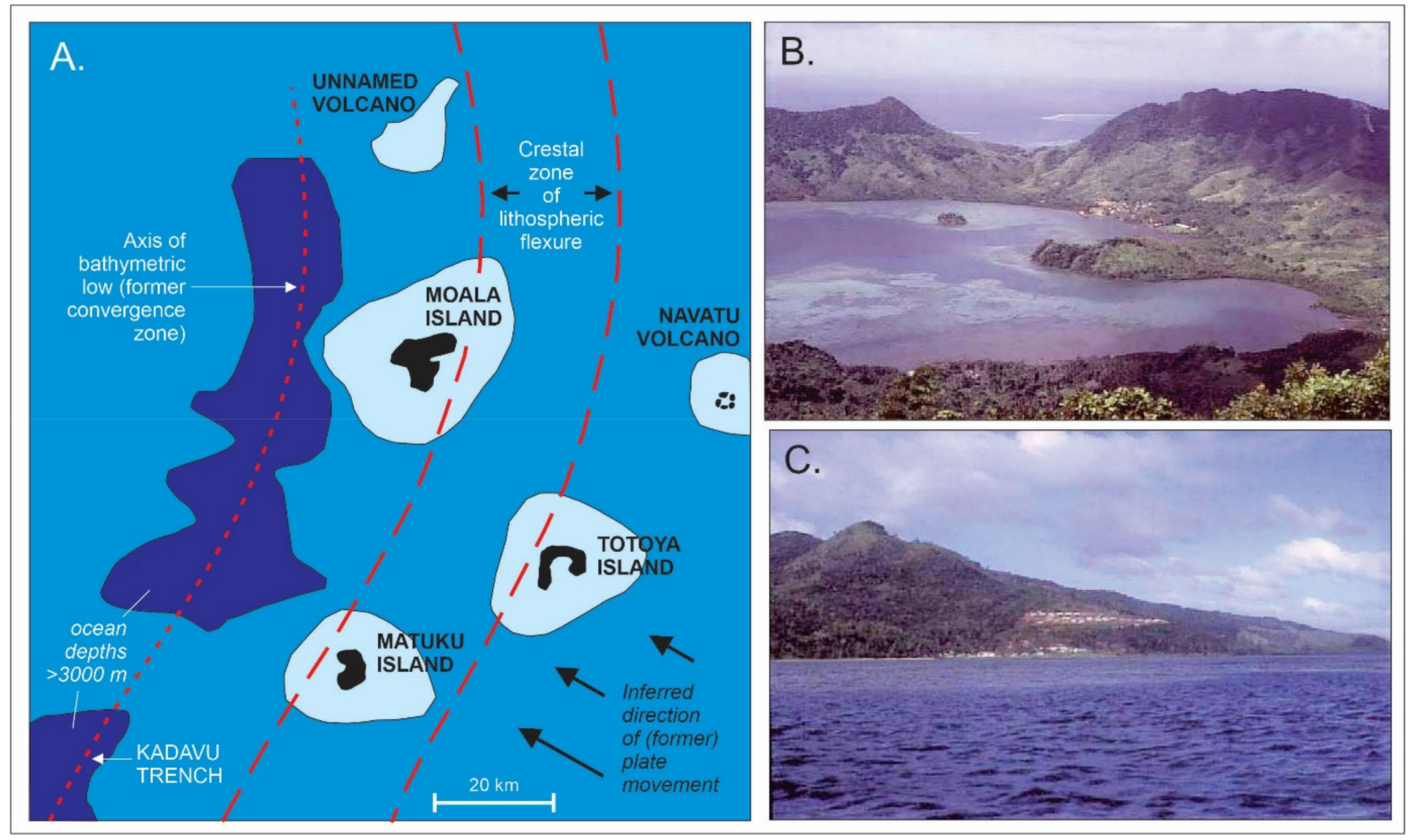

Figure 5. Lithospheric flexure in central Fiji and its implications for island tectonics. (A)—Map of the flexure (after 45), parallel to the axis of former plate convergence along the Kadavu Trench and its northeast extension, showing how Moala Island has passed over the crest and is now on its down-going flank, similar to Machias Seamount near Samoa [48], whereas Matuku Island is on its crest, like Maré and Lifou islands in New Caledonia [26] and Niue Island [49,50]. (B)—Extensional faulting formed the central rift valley (left to right on photo) of Moala Island. (C)—Subsidence-amplified sea-level rise necessitated the upslope relocation of Maloku Village on Moala in the 1980s [51]. (Photos: Patrick Nunn).

Roko Vola was the hereditary chief of Moala at the time of my visit and knew his people's stories well. One that still resonates with me today, decades later, is that of the American anthropologist Marshall Sahlins, who visited the island in the 1960s and wrote an influential book about its people and the ways they organized their lives [52]. Roko Vola's father had hosted Sahlins for nearly a year and, in gratitude, Sahlins had mailed his Moalan host a copy of this book. I still have this vivid image of Roko Vola explaining to me how his father had unwrapped the book, then taken a week to read the first few chapters, before tearing it down its spine and throwing it on the cooking fire- "we have no use for such fictions in our lives", Roko Vola's father had said. His son explained to me how his father opined that Sahlins had collected most of his information during the daytime when the only available informants were the layabouts who knew almost nothing but were prepared, in return for Sahlins supplying them with copious amounts of kava to drink, to invent all kinds of implausible details about Moalan life to sustain the satisfying interaction. Since then, I have always approached my research in the Pacific Islands with two questions in mind - how will this research benefit local residents, and will I waste their time? If the research does not pass the "Roko Vola test", I have abandoned it.

There are other instances where foreign priorities of no discernible value to Pacific peoples have been imposed on their island world. Examples abound in the fields of mining (discussed below), but also, more recently, in the management of risk that is supposedly defined in universal ways. For example, academics and journalists scramble to find new ways to highlight the vulnerability of Pacific Island nations to "climate change" but, as Pacific Islanders across the region have repeatedly told me, separating impact by cause is really unhelpful; people in a coastal community smashed by a giant wave are much less concerned about whether it is climate-driven or a tsunami, or even a distant-source wave of the kind that has temporarily submerged atoll islands recently [53]. All they see 
is a damaging wave. The need for a holistic impact-framed approach to risk and to risk management is far better aligned with Pacific worldviews.

Much of my research in the Pacific over the last twenty years has intersected with that of archaeologists, some of whom have proven welcoming and collegial, others decidedly less so. I first became involved with archaeology research in the region when I was approached by the Fiji Museum and invited to collaborate with them-something I am still doing. Why me, I asked at the time, to which the reply came that the Museum was becoming increasingly irked by foreign archaeologists coming to the Pacific and undertaking prolonged field research, before disappearing overseas with tea-chests full of samples and never sending anything back other than some obscure reference to some incomprehensible article in an academic journal. Communities were complaining. I had personal experience of one of these, which had facilitated excavations in a cave (Qwara $i$ $\mathrm{O}^{\prime}$ o) by a team of Australian archaeologists and who had failed, I was told, to return any information to the community, which had been keen to know more.

Models for the initial colonization of the South Pacific islands by Lapita peoples involve a general west-east movement from the Bismarck Archipelago (Papua New Guinea) about 3300 years ago to Samoa and Tonga around 2500 years ago [54]. Considering the open-ocean distances involved and the time at which these voyages evidently took place, few archaeologists have imagined people might have gone back west after discovering new lands. Yet, it seems to me that any group of ocean voyagers planning to settle unknown lands over the eastern horizon would have sent out exploratory groups in advance, to report back before the entire tribe invested in such a voyage. This idea is implicit in the work of Bill Dickinson, who compared the timing of atoll emergence with atoll colonization [55] and found a relationship suggestive of pre-knowledge; in other words, people were monitoring the condition of potentially habitable islands across the Pacific before they decided to settle them [56], possibly because they were "sea gypsies" rather than landlubbers [57].

One reason why this suggestion often makes some archaeologists almost apoplectic is that it runs contrary to the models they have nurtured for decades-but also because of a lack of evidence. This may just have been found and, while it will be published eventually, it is summarized here. On the Fiji island of Vanua Levu, close to its western extremity, the 19th-century geologist Henry Guppy came across something he named "the Mbua [Bua] Shell-Bed", which I was able to relocate a few years ago (Figure 6). It is comprised of just a few species of shell, all edible, and lies close to where the shoreline was probably located a few thousand years ago when the sea level was higher.

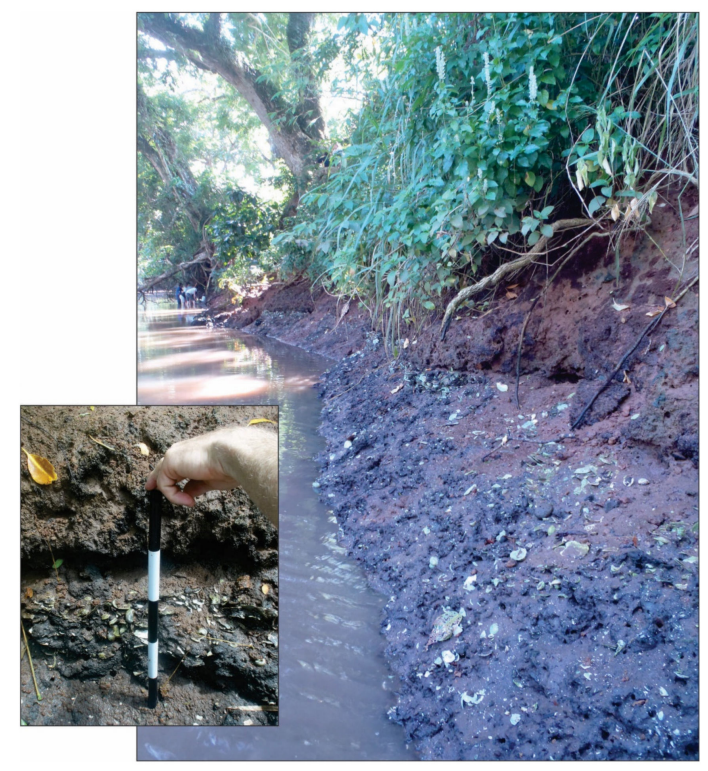

Figure 6. The rediscovered "Mbua Shell-Bed" may be evidence for an exploratory occupation of Fiji hundreds of years before the generally accepted time of first settlement (Photos: Patrick Nunn). 
Radiocarbon ages obtained thus far indicate that this shell bed, which is likely to be a midden, formed several hundred years before people are conventionally thought to have reached the Fiji Islands. It might represent a pioneer settlement by a group of ocean explorers who were either extinguished subsequently from history, or perhaps made it back to the islands in the west from which they had come to tell about the rich fertile land they had found-and inspire a wholesale migration. This research passes the Roko Vola test, not least because it highlights the unprecedented achievements of the earliest Pacific Islanders who succeeded in making ocean journeys of hundreds, sometimes thousands, of kilometers at a time when people everywhere else in the world rarely sailed intentionally out of sight of land.

\section{Island Futures for Island Peoples}

Lots of geoscience-linked issues will affect the future of the Pacific region, and I regret the world has not better equipped Pacific peoples to confront these issues and decide on ways forward that will benefit and sustain them. Discussed below are two of the most important groups of issues: firstly, the management of natural hazards, the impacts of which are likely to increase in the next few decades, and secondly the future of extractive industries across the region.

Pacific Island nations are uncommonly exposed to natural hazards, many climatedriven (like tropical cyclones, storm surges and drought), many geoscience-related (including earthquakes and tsunamis, volcanism and tectonism). Over the last few decades, a global narrative has developed that represents Pacific Island nations and their peoples as vulnerable and increasingly helpless in the face of such hazards. There have been many calls to fund the building of resilience within Pacific Island societies, calls made mostly by outsiders unaware of Pacific people's innate cultural resilience that has enabled them to survive for as much as 3500 years on oceanic islands distant from continental shores [29].

Outsider narratives have permeated Pacific Island nations largely because of the associated funding assistance, global and bilateral, which follows an acceptance of these narratives. Yet, especially in more rural/peripheral contexts in the Pacific region, there remains abundant societal resilience that is routinely employed (or has been until quite recently) to cope with disaster, both its anticipation and its aftermath [58-62]. Scholarly research into the nature and efficacy of Pacific people's coping with tsunami and volcanism, for example, focuses on culturally grounded early warning systems; fine examples come from Solomon Islands and Vanuatu [18,63-66]. Yet, this has barely been matched in the policy/aid space where the "helplessness narrative", which requires science-informed western/global interventions, dominates.

Hazards of this kind will continue to affect Pacific Island nations and their inhabitants, but there needs to be more than mere scholarly questioning of the most effective ways to assist them to cope and survive. For me, and certainly more than a handful of other geoscientists, the need to understand and foreground culturally grounded coping is key to this. Pacific Island peoples did not survive by sheer luck for millennia on their island homes. They evolved ways of survival that have of course become diminished by globalization (outsider contacts) and rendered generally less efficacious in some contexts by increased societal vulnerabilities (especially population growth and urbanization), yet these ancient ways are not for these reasons without worth.

A recent study focusing on external interventions for climate-change adaptation in the Pacific Islands [67] concluded that the vast majority had been much less impactful than anticipated, largely because they ignored local knowledge, privileged outsider worldviews over Pacific ones, and were dependent on cash. The study noted that implementers and donors should facilitate rather than drive adaptation; they should optimize community self-sufficiency and "help communities achieve local objectives equitably and effectively" (p. 638). This is a key message that straddles many areas of outsider-insider interaction in the Pacific Islands, not least in coping with geoscience-related hazards. For three decades, I have watched as local tsunami-alert systems requiring complex technologies and huge 
cash investment have been trialed in the Asia-Pacific region, but, while not intending to disparage the good intentions of those involved, I have yet to see such a system that even approaches the effectiveness of local knowledge $[63,64]$. More than this, I note a tendency for geoscientists to identify the "remarkable" examples of Pacific people's (non-Western) understandings of geological phenomena as anomalies, rather than realizing that these understandings represent the mere tip of Pacific people's knowledge about such things. This is a lazy and convenient default judgement, one that is unhelpful to the future of this region.

In the Introduction to this paper, I mentioned the challenges of managing the juxtaposition of contrasting worldviews and their associated value systems. In ending this paper, I want to focus on those value systems as they apply to the Pacific Islands. The region is suffused with Western-trained geoscientists whose unthinking mandate is to exploit the Earth's resources for sale and profit. In fact, one could argue that the principal reason for geologists' interests in the Pacific over the past hundred years or so has been the expectation of discovering profitable exportable reserves of gold and silver, copper and nickel, bauxite, phosphate, and even aggregate. Resource extraction has brought great profits for many mining companies, but it is very hard to argue that it has been either uniformly or sustainably beneficial to the peoples of the Pacific Islands.

The environmental and societal outfall of mining across the region, from Ok Tedi and Bougainville (Papua New Guinea) to Banaba (Kiribati) and Nauru, has displaced tens of thousands of Pacific Islanders; brought them into novel, sometimes violent, conflict and made their livelihoods precarious; and generally left them vastly impoverished compared to the situation before mining began [68-71]. In the Colo villages of the upper Wainimala, I have sat with former miners from the Vatukoula gold mine in Fiji and heard their horror stories about the conditions they endured there in the 1990s below ground (see also [72]); more recently, in coastal villages in northwest Bua in Fiji, I have listened to details of the massive and unprecedented impacts of bauxite strip mining on marine ecosystems, which will inevitably lead to food insecurity here in the future.

In recent decades, geologists' attention has broadened to include the possibility of seabed mining, especially for polymetallic nodules and cobalt-rich crusts that form on the flanks of subsiding volcanoes, and the polymetallic sulfides found along mid-ocean ridges [73]. Concern about the deleterious effects of seabed mining on ocean environments and the wellbeing of dependent populations is being increasingly discussed [74], as indeed it should.

Today, it is easy for these kinds of discussions to become polarized and for the ills and errors of past times to be sustained, even exaggerated, in a world where there is stronger environmental legislation and in which affected peoples often have a louder voice in global fora than they ever had before $[75,76]$. Yet despite this, it is clear to me that the history of mining in the Pacific Islands region has been one of almost unremitting exploitation of its natural resources. In this context, it is hugely encouraging to see Pacific leaders beginning to question the sustainability of foreign-driven resource extraction in the region [77]. For example, Fiji is backing a decade-long moratorium on seabed mining to allow scientific research into the Exclusive Economic Zones of Pacific Island nations that is expected to outline ways in which particular seabed resources can be sustainably mined, if that is indeed possible. It is a first step, I suggest, in a long journey by which Pacific interests can recapture control over the issues that might in the future affect Pacific peoples more than most.

\section{Conclusions}

There are ways to marry Pacific knowledges and values with more widely documented ("global") understandings of the Earth and the ways these can benefit humanity. In various fields of scholarship and its application, I consider we are on the cusp of recognizing non-Western worldviews as at least equally as able to map out agendas for our future 
development, whether these refer to coping with challenges in a warming, increasingly crowded world, or to the management of natural resources [78,79].

A new generation of Pacific Island geoscientists needs to be trained, not in the irrelevant geotectonic contexts of the continents, but on islands where they will not merely receive a solid grounding in the issues affecting island futures, but where they will also access the understandings of people who have been intimate with these settings for millennia.

Funding: This research received no external funding.

Acknowledgments: I cannot adequately thank the countless people, geoscientists of many hues and diverse qualification, who have generously shared their insights with me over the past few decades. I also want to thank those who made this journey possible. From the uncomplaining Navoha tobacco farmer who helped me manage two punctures one evening in the pouring rain, to the prescient boatman who produced a second outboard motor after the first one dropped off the back of the boat in which we were traveling between Moala and Totoya, to all the people who ungrudgingly gave me a bed in their homes, all those who guided me up hills, hauled me up crumbling rock faces, cut paths for me through dense bush, chased away the wild pigs and toxic millipedes, crushed leaves and plastered them on my gashes and bruises with astonishing effect. Additionally, to Rosie and Petra, who did many of those things as well.

Conflicts of Interest: The author declares no conflict of interest.

\section{References}

1. Nunn, P.D. Oceanic Islands; Blackwell: Oxford, UK, 1994.

2. Nunn, P.D. Coastal geomorphology of Beqa and Yanuca Islands, South Pacific Ocean, and its significance for the tectonic history of the Vatulele-Beqa Ridge. Pac. Sci. 1990, 4, 348-365.

3. Vitaliano, D. Legends of the Earth: Their Geologic Origins; Indiana University Press: Bloomington, IN, USA, 1973.

4. Piccardi, L.; Masse, W.B. (Eds.) Myth and Geology; Geological Society of London: London, UK, 2007 ; p. 350.

5. Taylor, P.W. Myths, legends and volcanic activity-An example from northern Tonga. J. Polyn. Soc. 1995, 104, 323-346.

6. Cashman, K.V.; Cronin, S.J. Welcoming a monster to the world: Myths, oral tradition, and modern societal response to volcanic disasters. J. Volcanol. Geotherm. Res. 2008, 176, 407-418. [CrossRef]

7. Ballard, C. The Lizard in the Volcano: Narratives of the Kuwae Eruption. Contemp. Pac. 2020, 32, 98-123. [CrossRef]

8. Carson, M.T.; Athens, J.S. Integration of coastal geomorphology, mythology, and archaeological evidence at Kualoa Beach, windward O'ahu, Hawaiian Islands. J. Isl. Coast. Archaeol. 2007, 2, 24-43. [CrossRef]

9. Nunn, P.D. The Edge of Memory: Ancient Stories, Oral Tradition and the Post-Glacial World; Bloomsbury: London, UK, 2018.

10. Nunn, P.D. Worlds in Shadow: Submerged Lands in Science, Memory and Myth; Bloomsbury: London, UK, 2021.

11. Purzycki, B.G.; Apicella, C.; Atkinson, Q.D.; Cohen, E.; McNamara, R.A.; Willard, A.K.; Xygalatas, D.; Norenzayan, A.; Henrich, J. Moralistic gods, supernatural punishment and the expansion of human sociality. Nature 2016, 530, 327-330. [CrossRef]

12. Donner, S.D. Domain of the Gods: An editorial essay. Clim. Chang. 2007, 85, 231-236. [CrossRef]

13. Ballard, C.; McDonnell, S.; Calandra, M. Confronting the Naturalness of Disaster in the Pacific. Anthropol. Forum 2020, 30, 1-14. [CrossRef]

14. Smith, W. Weather from incest: The politics of indigenous climate change knowledge on Palawan Island, the Philippines. Aust. J. Anthropol. 2018, 29, 265-281. [CrossRef]

15. Schlehe, J. Cultural politics of natural disasters: Discourses on volcanic eruptions in Indonesia. In Culture and the Changing Environment: Uncertainty, Cognition, and Risk Management in Cross-Cultural Perspective; Casimir, M.J., Ed.; Berghahn: Oxford, UK, 2008; pp. 275-299.

16. Nunn, P.D. Lashed by sharks, pelted by demons, drowned for apostasy: The value of myths that explain geohazards in the Asia-Pacific region. Asian Geogr. 2014, 31, 59-82. [CrossRef]

17. Cronin, S.J.; Cashman, K.V. Volcanic oral traditions in hazard assessment and mitigation. In Living under the Shadow: Cultural Impacts of Volcanic Eruption; Gratton, J., Torrence, R., Eds.; Left Coast Press: Oakland, CA, USA, 2008; pp. $175-202$.

18. Cronin, S.J.; Gaylord, D.R.; Charley, D.; Alloway, B.V.; Wallez, S.; Esau, J.W. Participatory methods of incorporating scientific with traditional knowledge for volcanic hazard management on Ambae Island, Vanuatu. Bull. Volcanol. 2004, 66, 652-668. [CrossRef]

19. Cronin, S.J.; Neall, V.E. Holocene volcanic geology, volcanic hazard, and risk on Taveuni, Fiji. N. Z. J. Geol. Geophys. 2001, 44, 417-437. [CrossRef]

20. Nunn, P.D. Fished up or thrown down: The geography of Pacific Island origin myths. Ann. Assoc. Am. Geogr. 2003, 93, 350-364. [CrossRef]

21. Nunn, P.D. Vanished Islands and Hidden Continents of the Pacific; University of Hawai'i Press: Honolulu, HI, USA, 2009 ; p. 269.

22. Cronin, S.J.; Ferland, M.A.; Terry, J.P. Nabukelevu volcano (Mt. Washington), Kadavu-A source of hitherto unknown volcanic hazard in Fiji. J. Volcanol. Geotherm. Res. 2004, 131, 371-396. [CrossRef] 
23. Nunn, P.D. Pacific Island Landscapes: Landscape and Geological Development of Southwest Pacific Islands, Especially Fiji, Samoa and Tonga; Institute of Pacific Studies, University of the South Pacific: Suva, Fiji, 1998.

24. Dickinson, W.R. Temper Sands in Prehistoric Oceanian Pottery: Geotectonics, Sedimentology, Petrography, Provenance; Geological Society of America: Boulder, CO, USA, 2006.

25. Dickinson, W.R. Impacts of eustasy and hydro-isostasy on the evolution and landforms of Pacific atolls. Paleogeogr. Paleoclimatol. Paleoecol. 2004, 213, 251-269. [CrossRef]

26. Dickinson, W.R. Control of paleoshorelines by trench forebulge uplift, Loyalty Islands. Quat. Res. 2013, 80, 125-137. [CrossRef]

27. Dickinson, W.R. Hydro-isostatic and tectonic influences on emergent Holocene paleoshorelines in the Mariana Islands, western Pacific Ocean. J. Coast. Res. 2000, 16, 735-746.

28. Nunn, P.D. Holocene sea-level change and human response in Pacific Islands. Earth Environ. Sci. Trans. R. Soc. Edinb. 2007, 98, 117-125. [CrossRef]

29. Nunn, P.D. Climate, Environment and Society in the Pacific during the Last Millennium; Elsevier: Amsterdam, The Netherlands, 2007.

30. Nunn, P.D. Na koronivalu ni Bā: Upland settlement during the last millennium in the Bā River Valley and Vatia Peninsula, northern Viti Levu Island, Fiji. Asian Perspect. 2012, 51, 1-21. [CrossRef]

31. Nunn, P.D.; Nakoro, E.; Tokainavatu, N.; McKeown, M.; Geraghty, P.; Thomas, F.R.; Martin, P.; Hourigan, B.; Kumar, R. A Koronivalu kei Bua: Hillforts in Bua Province (Fiji), their chronology, associations, and potential significance. J. Isl. Coast. Archaeol. 2019, 1-29. [CrossRef]

32. Nunn, P.D.; Nakoro, E.; Kumar, R.; Nanuku, M.; Camailakeba, M. How island peoples adapt to climate change: Insights from studies of Fiji's hillforts. In Palaeolandscapes in Archaeology: Lessons for the Past and Future; Carson, M.T., Ed.; Routledge: London, UK, 2021.

33. Lilomaiava-Doktor, S. Oral Traditions, Cultural Significance of Storytelling, and Samoan Understandings of Place or Fanua. Nais-Nativ. Am. Indig. Stud. Assoc. 2020, 7, 121-151. [CrossRef]

34. Nunn, P.D.; Lancini, L.; Franks, L.; Compatangelo-Soussignan, R.; McCallum, A. Maar stories: How oral traditions aid understanding of maar volcanism and associated phenomena during pre-literate times. Ann. Am. Assoc. Geogr. 2019, 109, $1618-1631$. [CrossRef]

35. Beck, R.J. New Zealand Jade: The Story of Greenstone; Reed: Wellington, New Zealand, 1970.

36. Nunn, P.D. Geographical influences on settlement-location choices by initial colonizers: A case study of the Fiji Islands. Geogr. Res. 2009, 47, 306-319. [CrossRef]

37. Nunn, P.D.; Kumar, R.; Matararaba, S.; Ishimura, T.; Seeto, J.; Rayawa, S.; Kuruyawa, S.; Nasila, A.; Oloni, B.; Ram, A.R.; et al. Early Lapita settlement site at Bourewa, southwest Viti Levu Island, Fiji. Archaeol. Ocean. 2004, 39, 139-143. [CrossRef]

38. Geraghty, P. Pulotu, Polynesian homeland. J. Polyn. Soc. 1993, 102, 343-384.

39. Dickinson, W.R.; Nunn, P.D. Petrography of sand tempers in Lapita potsherds from the Rove Peninsula, Southwest Viti Levu, Fiji. J. Pac. Archaeol. 2013, 4, 1-17.

40. Nunn, P.D. Echoes from a distance: Progress report on research into the Lapita occupation of the Rove Peninsula, southwest Viti Levu Island, Fiji. In Oceanic Explorations: Lapita and Western Pacific Settlement; Bedford, S., Sand, C., Connaughton, S., Eds.; Australian National University: Canberra, Australia, 2007; Volume 26, pp. 163-176.

41. Nunn, P.D.; Heorake, T.; Tegu, E.; Oloni, B.; Simeon, K.; Wini, L.; Usuramo, S.; Geraghty, P. Geohazards revealed by myths in the Pacific: A study of islands that have disappeared in Solomon Islands. S. Pac. Stud. 2006, 27, 37-49.

42. Phinney, E.J.; Mann, P.; Coffin, M.F.; Shipley, T.H. Sequence stratigraphy, structural style, and age of deformation of the Malaita accretionary prism (Solomon arc-Ontong Java Plateau convergent zone). Tectonophysics 2004, 389, 221-246. [CrossRef]

43. Bhardwaj, A.; Sam, L.; Martin-Torres, F.J. The challenges and possibilities of earthquake predictions using non-seismic precursors. Eur. Phys. J. Spec. Top. 2021, 230, 367-380. [CrossRef]

44. Whitehead, N.E.; Ulusoy, U.; Asahara, H.; Ikeya, M. Are any public-reported earthquake precursors valid? Nat. Hazards Earth Syst. Sci. 2004, 4, 463-468. [CrossRef]

45. Lawry, W. Friendly and Feejee Islands: A Missionary Visit; Charles Gilpin: London, UK, 1850.

46. Wadhawan, M.; Rana, N.; Gahalaut, V.; Singh, M.; Singh, K.; Suresh, G.; Mishra, O.P.; Joshi, A.K.; Kulkarni, A.V.; Das, A.K. Monsoonal rainfall induced shallow earthquake Swarm in the Amravati district of the central India. J. Earth Syst. Sci. 2021, 130, 29. [CrossRef]

47. Nunn, P.D. Lithospheric flexure in southeast Fiji consistent with the tectonic history of islands in the Yasayasa Moala. Aust. J. Earth Sci. 1995, 42, 377-389. [CrossRef]

48. Coulbourn, W.T.; Hill, P.J.; Bergersen, D.D. Machias Seamount, Western Samoa: Sediment remobilization, tectonic dismemberment and subduction of a guyot. Geo-Mar. Lett. 1989, 9, 119-125. [CrossRef]

49. Kennedy, D.M.; Marsters, T.H.; Woods, J.L.D.; Woodroffe, C.D. Shore platform development on an uplifting limestone island over multiple sea-level cycles, Niue, South Pacific. Geomorphology 2012, 141, 170-182. [CrossRef]

50. Nunn, P.D.; Britton, J.M.R. The long-term evolution of Niue Island. In Geographical Perspectives on the Rock of Polynesia; Terry, J., Murray, W., Eds.; INSULA: Paris, France, 2004; pp. 31-74.

51. Janif, S.; Nunn, P.D.; Geraghty, P.; Aalbersberg, W.; Thomas, F.R.; Camailakeba, M. Value of traditional oral narratives in building climate-change resilience: Insights from rural communities in Fiji. Ecol. Soc. 2016, 21. [CrossRef]

52. Sahlins, M. Moala: Culture and Nature on a Fijian Island; University of Michigan Press: Ann Arbor, MI, USA, 1962. 
53. Hoeke, R.K.; McInnes, K.L.; Kruger, J.C.; McNaught, R.J.; Hunter, J.R.; Smithers, S.G. Widespread inundation of Pacific islands triggered by distant-source wind-waves. Glob. Planet. Chang. 2013, 108, 128-138. [CrossRef]

54. Carson, M.T.; Hung, H.-c.; Summerhayes, G.; Bellwood, P. The pottery trail from Southeast Asia to Remote Oceania. J. Isl. Coast. Archaeol. 2013, 8, 17-36. [CrossRef]

55. Dickinson, W.R. Impact of mid-holocene hydro-isostatic highstand in regional sea level on habitability of islands in Pacific Oceania. J. Coast. Res. 2003, 19, 489-502.

56. Nunn, P.D. Sea levels, shorelines and settlements on Pacific reef islands. Archaeol. Ocean. 2015, 51, 91-98. [CrossRef]

57. Di Piazza, A.; Pearthree, E. The spread of the 'Lapita people': A demographic simulation. J. Artif. Soc. Soc. Simul. 1999, 2, 1-4.

58. Trundle, A.; Barth, B.; McEvoy, D. Leveraging endogenous climate resilience: Urban adaptation in Pacific Small Island Developing States. Environ. Urban. 2019, 31, 53-74. [CrossRef]

59. Walshe, R.A.; Seng, D.C.; Bumpus, A.; Auffray, J. Perceptions of adaptation, resilience and climate knowledge in the Pacific: The cases of Samoa, Fiji and Vanuatu. Int. J. Clim. Chang. Strateg. Manag. 2018, 10, 303-322. [CrossRef]

60. Nalau, J.; Becken, S.; Schliephack, J.; Parsons, M.; Brown, C.; Mackey, B. The Role of Indigenous and Traditional Knowledge in Ecosystem-Based Adaptation: A Review of the Literature and Case Studies from the Pacific Islands. Weather Clim. Soc. 2018, 10, 851-865. [CrossRef]

61. Nunn, P.D.; Runman, J.; Falanruw, M.; Kumar, R. Culturally grounded responses to coastal change on islands in the Federated States of Micronesia, northwest Pacific Ocean. Reg. Environ. Chang. 2017, 17, 959-971. [CrossRef]

62. McMillen, H.L.; Ticktin, T.; Springer, H.K. The future is behind us: Traditional ecological knowledge and resilience over time on Hawai'i Island. Reg. Environ. Chang. 2017, 17, 579-592. [CrossRef]

63. Walshe, R.A.; Nunn, P.D. Integration of indigenous knowledge and disaster risk reduction: A case study from Baie Martelli, Pentecost Island, Vanuatu. Int. J. Disaster Risk Sci. 2012, 3, 185-194. [CrossRef]

64. McAdoo, B.G.; Moore, A.; Baumwoll, J. Indigenous knowledge and the near field population response during the 2007 Solomon Islands tsunami. Nat. Hazards 2009, 48, 73-82. [CrossRef]

65. Németh, K.; Cronin, S.J. Volcanic structures and oral traditions of volcanism of Western Samoa (SW Pacific) and their implications for hazard education. J. Volcanol. Geotherm. Res. 2009, 186, 223-237. [CrossRef]

66. Petterson, M.; Cronin, S.; Taylor, P.; Tolia, D.; Papabatu, A.; Toba, T.; Qopoto, C. The eruptive history and volcanic hazards of Savo, Solomon Islands. Bull. Volcanol. 2003, 65, 165-181. [CrossRef]

67. McNamara, K.E.; Clissold, R.; Westoby, R.; Piggott-McKellar, A.; Kumar, R.; Clarke, T.; Namoumou, F.; Areki, F.; Joseph, E.; Warrick, O.; et al. An assessment of community-based adaptation initiatives in the Pacific Islands. Nat. Clim. Chang. 2020, 10, 628-639. [CrossRef]

68. Busilacchi, S.; Butler, J.R.A.; Rochester, W.A.; Posu, J. Drivers of illegal livelihoods in remote transboundary regions: The case of the Trans-Fly region of Papua New Guinea. Ecol. Soc. 2018, 23. [CrossRef]

69. Jewkes, R.; Jama-Shai, N.; Sikweyiya, Y. Enduring impact of conflict on mental health and gender-based violence perpetration in Bougainville, Papua New Guinea: A cross-sectional study. PloS ONE 2017, 12, e0186062. [CrossRef] [PubMed]

70. Teaiwa, K.M. Consuming Ocean Island: Stories of People and Phosphate from Banaba; Indiana University Press: Bloomington, IN, USA, 2014.

71. Morris, J.C. Violence and extraction of a human commodity: From phosphate to refugees in the Republic of Nauru. Extr. Ind. Soc. Int. J. 2019, 6, 1122-1133. [CrossRef]

72. Emberson-Bain, A. Labour and Gold in Fiji; Cambridge University Press: Cambridge, UK, 1994.

73. Miller, K.A.; Thompson, K.F.; Johnston, P.; Santillo, D. An Overview of Seabed Mining Including the Current State of Development, Environmental Impacts, and Knowledge Gaps. Front. Mar. Sci. 2018, 4, 418. [CrossRef]

74. Ardron, J.A.; Simon-Lledo, E.; Jones, D.O.B.; Ruhl, H.A. Detecting the Effects of Deep-Seabed Nodule Mining: Simulations Using Megafaunal Data From the Clarion-Clipperton Zone. Front. Mar. Sci. 2019, 6, 604. [CrossRef]

75. Kakee, T. Deep-sea mining legislation in Pacific Island countries: From the perspective of public participation in approval procedures. Mar. Policy 2020, 117, 103881. [CrossRef]

76. Komaki, K.; Fluharty, D. Options to Improve Transparency of Environmental Monitoring Governance for Polymetallic Nodule Mining in the Area. Front. Mar. Sci. 2020, 7, 247. [CrossRef]

77. Kung, A.; Svobodova, K.; Lebre, E.; Valenta, R.; Kemp, D.; Owen, J.R. Governing deep sea mining in the face of uncertainty. J. Environ. Manag. 2021, 279, 111593. [CrossRef] [PubMed]

78. Godden, L.; Langton, M.; Mazel, O.; Tehan, M. Accommodating Interests in Resource Extraction: Indigenous Peoples, Local Communities and the Role of Law in Economic and Social Sustainability. J. Energy Nat. Resour. Law 2008, 26, 1-30. [CrossRef]

79. Langton, M.; Mazel, O. Poverty in the Midst of Plenty: Aboriginal People, the 'Resource Curse' and Australia's Mining Boom. J. Energy Nat. Resour. Law 2008, 26, 31-65. [CrossRef] 